\title{
Инициативы Казахстана в области экономической и транспортной взаимосвязанности в рамках ОБСЕ: стимулирование торговли и сопротивление нормам
}

\author{
Себастьян Майер*
}

\section{Аннотаиия}

В течение 2010-х годов в контексте второго (экономического и экологического) измерения безопасности ОБСЕ стало модно говорить о «взаимосвязанности» как политическом инструменте для улучшения экономических отношений между государствами-участниками. Казахстан предложил разместить в его столице центр ОБСЕ по вопросам взаимосвязанности для предоставления соответствующих экспертных услуг. В статье для «ОБСЕ Insights» рассмотрены сама концепция взаимосвязанности и повестка дня Казахстана в этой области, анализируются мотивы, связанные с инициативами Казахстана. Помимо очевидной заинтересованности этой не имеющей выхода к морю страны в повышении международной транспортной взаимосвязанности Казахстан, как представляется, использует продвижение своих инициатив для того, чтобы отвлечь внимание от его обязательств в рамках первого (военно-политического) и особенно третьего (человеческого) измерений безопасности. Автор полагает, что к предложениям Казахстана следует отнестись серьезно не только потому, что ОБСЕ действительно может играть определенную роль в повышении взаимосвязанности, но и потому, что значительный вклад Казахстана в региональное и международное сотрудничество и обеспечение стабильности заслуживает признания. Вместе с тем подчеркивается, что три измерения безопасности ОБСЕ не могут быть противопоставлены друг другу и что Казахстан должен продолжать уделять внимание своим обязательствам по первому и третьему измерениям.

\section{Ключевые слова}

Взаимосвязанность, экономические отношения, ОБСЕ, Центральная Азия, Казахстан, содействие развитию торговли, сопротивление нормам

Для цитирования этой публикации: Майер С. Инициативы Казахстана в области экономической и транспортной взаимосвязанности в рамках ОБСЕ: стимулирование торговли и сопротивление нормам // ОБСЕ Insights 4. - Баден-Баден: Номос, 2021. URL: https://doi.org/10.5771/ 9783748921264-04

* Себастьян Майер, доктор наук, Германская служба академических обменов, КазахстанскоГерманский университет Алматы, Казахстан, mayer@dku.kz 


\section{Введение}

В 2010-е годы стало модно говорить о «взаимосвязанности» как политическом инструменте для улучшения межгосударственных экономических отношений, особенно в странах Юго-Восточной и Восточной Европы с переходной экономикой и в бывшем Советском Союзе. В ОБСЕ этот термин начали использовать в период председательства Германии в ОБСЕ в 2016 году, но теме улучшения экономических отношений была посвящена уже вторая глава хельсинкского Заключительного акта 1975 года. На сайте ОБСЕ говорится, что организация „работает над созданием основы экономической взаимосвязанности 57 государств-участников посредством диалога по вопросам торговли и транспорта"102.

Казахстан сделал тему взаимосвязанности центральной в своей внешней политике. Это неудивительно, учитывая отсутствие у него выхода к морю и общую изолированность от глобальных рынков. На этом фоне правительство выдвинуло предложение создать в столице страны Нур-Султане Тематический центр ОБСЕ по устойчивой взаимосвязанности. Такой центр предоставил бы стране возможность воспользоваться соответствующими экспертными знаниями. Однако у Казахстана есть и другие причины для продвижения дискуссии о взаимосвязанности в рамках ОБСЕ. Акцент на этой теме способствовал бы реализации его претензии на роль международного и регионального лидера. Уделение особого внимания вопросам второго (экономического и экологического) измерения безопасности, таким как взаимосвязанность, позволило бы отодвинуть на второй план неприятные для Казахстана обязательства по двум другим измерениям ОБСЕ - военно-политическому и человеческому. Это особенно верно в отношении последнего, поскольку руководство страны по-прежнему сопротивляется реформам, особенно в том, что касается основных свобод, выборов и свободы политических партий. Есть основания полагать, что правительство Казахстана хотело бы заменить нынешний Программный офис ОБСЕ в Нур-Султане, занимающийся вопросами всех трех измерений, тематическим центром, который будет заниматься только вторым.

Помимо рассмотрения самой концепции взаимосвязанности и ее обсуждения в ОБСЕ основные цели настоящей статьи заключаются в том, чтобы очертить повестку дня Казахстана в области взаимосвязанности, делая акцент на предложении о создании центра, обрисовать ее побудительные мотивы и сформулировать предложения о том, как ОБСЕ могла бы реагировать на инициативы этого государства. В статье утверждается, что к инициативе Казахстана следует относиться серьезно не только потому, что ОБСЕ действительно может играть определенную роль в обеспечении взаимосвязанности, но и потому, что вклад Казахстана в региональное и международное сотрудничество и стабильность заслуживает признания. В то же время в статье указывается на то, что три измерения ОБСЕ нельзя противопоставлять друг другу и что Казахстан должен продолжать уделять внимание своим обязательствам по первому и третьему измерениям. 
В начале статьи раскрывается содержание концепции взаимосвязанности. Во втором разделе говорится о том, как эта тема была привнесена в повестку дня ОБСЕ. В следующих двух разделах показано, как Казахстан в своей внешней политике делает акцент на взаимосвязанность, и освещены основные мотивы этой политики. На основе проведенного анализа в последнем разделе сформулированы рекомендации для ОБСЕ 103 .

\section{Концепция взаимосвязанности}

В контексте настоящей статьи «взаимосвязанность» можно условно определить как целенаправленное выстраивание экономических отношений между государствами или регионами ${ }^{104}$. Будучи инструментом международной политики по содействию развитию, она является элементом экономической дипломатии, осуществляемой отдельными государствами и международными организациями. Если более ранние исследования межгосударственных отношений, такие как работы Роберта Кохейна и Джозефа Ная, были сосредоточены на анализе нарастающего экономического взаимодействия между промышленно развитыми странами ${ }^{105}$, то экономика стран бывшего социалистического блока оказалась в центре внимания ученых и практиков лишь после падения Берлинской стены в 1989 году. Взаимосвязанность рассматривалась как один из основных двигателей экономического прогресса этих государств. Примерами инициатив по формированию экономической взаимосвязанности могут служить уже завершенная программа технического содействия странам Содружества Независимых Государств (TACIS), инициированная в 1991 году тогда еще Европейскими сообществами; инициатива «Пояс и путь», объявленная Китаем в 2013 году; японская инициатива «Партнерство в интересах качественной инфраструктуры», выдвинутая в 2015 году, и стратегия Европейского союза по взаимосвязанности Европы и Азии, осуществление которой было начато в 2018 году. Помимо ощутимых материальных выгод взаимосвязанность потенциально может служить укреплению доверия и развитию мирных отношений между участвующими государствами ${ }^{106}$. Эти ожидания соответствуют направлению либеральной мысли, согласно которому экономический обмен способствует стабильности и миру.

Государства поддерживают проекты по обеспечению взаимосвязанности, поскольку они отвечают их материальным интересам и (или) служат более широким целям. Но помимо выгод, которые приносит взаимосвязанность, она сопряжена и с рисками. Как отмечают Кохейн и Най, расширение экономических отношений в той или иной степени может повысить уязвимость национальной экономики ${ }^{107}$, о чем свидетельствуют нефтяное эмбарго 1970-х годов, торговые войны и сбои в поставках, подобные тем, которые возникли в результате недавнего распространения COVID-19. Расхождения относительно того, с кем и как предпочтительно развивать экономические отношения, могут стать дополнительным источником трений, веду- 
щих к их политизации. Более того, термин «взаимосвязанность» имеет совершенно различные коннотации, что также может порождать разногласия ${ }^{108}$. Автократические государства - ярким примером может служить Китай, выдвинувший инициативу «Пояс и путь» - по большому счету ограничиваются связями ненормативного, материального характера, уделяя основное внимание физической инфраструктуре и связанным с ней стратегическим расчетам. В либеральных государствах и международных институтах, напротив, эта концепция, как правило, сочетается с определенными нормативными требованиями, включая вышеупомянутые ожидания либерального мира. Соответствующие концепции, такие как надлежащее управление и устойчивое развитие, предполагают соблюдение в рамках деятельности по укреплению взаимосвязанности ряда руководящих принципов, ценностей и норм. Такие принципы сформулированы и ОБСЕ.

\section{ОБСЕ и взаимосвязанность}

Обсуждение вопросов взаимосвязанности в ОБСЕ восходит к хельсинкскому Заключительному акту 1975 года, вторая глава которого посвящена экономическому и экологическому сотрудничеству. Несколько принятых в период после окончания «холодной войны» основополагающих документов, относящихся ко второму измерению, проложили дальнейший путь в этой сфере деятельности. Документ боннской Конференции по экономическому сотрудничеству в Европе 1990 года призывает к «устойчивому экономическому росту» и «сотрудничеству в области экономики», подчеркивая значение принципов «правового государства и равной защиты со стороны закона для всех на основе уважения прав человека и эффективных, доступных и справедливых правовых систем» ${ }^{109}$.

Особенно важный Документ-стратегия ОБСЕ в области экономического и экологического измерения (Маастрихтский документ) был принят на встрече Совета министров в 2003 году в Маастрихте на фоне значительных трудностей, с которыми столкнулись экономические преобразования в бывших социалистических странах. Был выделен ряд проблем в области управления, такие как «неэффективность институтов и слабость гражданского общества, отсутствие транспарентности и подотчетности в государственном и частном секторах, ... неудовлетворительная работа органов государственного управления и неустойчивое использование природных ресурсов, коррупция и неуважение к деловой этике и надлежащим процедурам корпоративного управления» ${ }^{110}$.

На встречах Совета министров в 2006 (Брюссель) и 2011 (Вильнюс) годах также были приняты решения, связанные с экономическим сотрудничеством. Обсуждению этой темы был придан значительный импульс в 2014 году, когда швейцарское председательство поставило ее на первое место в повестке дня ОБСЕ. В решении о совершенствовании надлежащего управления и повышении взаимосвязанности, 
принятом на встрече Совета министров в 2016 году в Гамбурге, впервые в контексте ОБСЕ было употреблено модное слово «взаимосвязанность». При этом было отмечено, что «надлежащее управление, транспарентность и подотчетность являются необходимыми условиями для экономического роста, торговли, инвестиций и устойчивого развития, способствуя тем самым обеспечению стабильности, безопасности и уважения прав человека». В этом решении органам ОБСЕ было поручено активизировать работу по упрощению, гармонизации и стандартизации правил и положений, касающихся торговли в регионе ОБСЕ. Более поздние документы, касающиеся взаимосвязанности, включают решение Совета министров 2017 года о содействии участию в экономической жизни в регионе ОБСЕ и Декларацию Совета министров о цифровой экономике как двигателе сотрудничества, безопасности и роста 2018 года.

Все вышеупомянутые документы основаны на предположении, что содействие экономическому процветанию и обеспечению необходимых для этого условий в соответствии с концепцией взаимосвязанности укрепляет безопасность и стабильность в регионе ОБСЕ. Однако в силу различий в акцентах и значительных различий в типах политических режимов государств-участников подход ОБСЕ к взаимосвязанности, несомненно, многогранен. Поэтому отсутствует консенсус в отношении того, как точно определить взаимосвязанность в рамках ОБСЕ.

В институциональных рамках ОБСЕ вопросами взаимосвязанности занимается Бюро координатора экономической и экологической деятельности ОБСЕ (БКЭЭД ОБСЕ). Его мандат основывается на вышеупомянутых решениях и декларациях, в частности на Маастрихтском документе 2003 года. 22 сотрудника бюро занимаются всем спектром деятельности ОБСЕ во втором измерении, включая взаимосвязанность и другие смежные области, такие как внедрение цифровых технологий и надлежащее управление ${ }^{111}$.

В географическом плане обсуждение вопросов взаимосвязанности в ОБСЕ сфокусировано на Восточной Европе, Юго-Восточной Европе, Южном Кавказе и Центральной Азии. Как и в других областях деятельности ОБСЕ, БКЭЭД выполняет свой мандат в отношении экономического сотрудничества государств в основном путем обобщения наилучших практик для лиц, ответственных за разработку политики, и специалистов-практиков. Например, он выпустил Справочник по передовой практике на пунктах пересечения границы ${ }^{112}$ и опубликовал материалы Форума по безопасности на внутреннем транспорте ${ }^{113}$, которые были подготовлены совместно с Европейской экономической комиссией ООН. Кроме того, БКЭЭД организует рабочие совещания, семинары и онлайновые мероприятия по тематике, связанной с обеспечением взаимосвязанности, на национальном и региональном уровнях, а также на уровне штаб-квартир. Проведенные до настоящего времени мероприятия охватывают трансграничную электронную торговлю, координацию транзита и безбумажную торговлю. Например, в июне 2020 года было проведено онлайн-совещание на тему «Более безопасные и устойчивые цепочки поставок, соединяющие Цен- 
тральную Азию и Европу». Пока неясно, сможет ли предложенный Казахстаном центр по взаимосвязанности взять на себя соответствующие функции БКЭЭД и в какой степени.

\section{Инициативы Казахстана в области взаимосвязанности в рамках ОБСЕ}

В не имеющей выхода к морю Центральной Азии, которую некоторые наблюдатели считают одним из наименее интегрированных регионов мира, взаимосвязанность и, в частности, транспорт, безусловно, имеет особое значение в том числе с учетом высоких транзитных издержек ${ }^{114}$. Для Казахстана уже в течение некоторого времени взаимосвязанность - приоритет внешней политики, значение которого за последние несколько лет еще больше возросло. Как член Евразийского экономического союза (ЕАЭС) страна заинтересована в развитии торговли с другими членами ЕАЭС. Она также активно поддерживает китайскую инициативу «Пояс и путь», которая была анонсирована в столице Казахстана в 2013 году. Для реализации проекта «Пояс и путь» Казахстан имеет стратегическое значение как коридор, по которому осуществляются перевозки между Китаем и Западом. Осуществление этой инициативы также может улучшить транзитное сообщение между странами-членами ЕАЭС 115. Правительство Казахстана тесно связало с «Поясом и путем» свою собственную программу развития инфраструктуры «Нурлы Жол» («Светлый путь»), в которой внимание сосредоточено на железнодорожном и автомобильном сообщении ${ }^{116}$.

На этом фоне Казахстан отдал приоритет деятельности в сфере взаимосвязанности в основном потому, что она помогает модернизировать существующие маршруты и диверсифицировать торговлю за счет разработки новых маршрутов - главным образом, помогая снизить транспортные расходы, - получать доходы от транзитных сборов и компенсировать нестабильность экспорта, порождаемую чрезмерной зависимостью от немногочисленных рынков. Для Китая Казахстан имеет решающее значение как транспортный коридор и для импорта, и для экспорта. Кроме того, он источник таких сырьевых товаров, как нефть и уран. Однако с «Поясом и путем» и другими проектами по расширению коммуникационных возможностей постоянно возникают проблемы, такие как недостаточная стандартизация торговли и транзитных трансграничных перевозок, отсутствие прозрачности, верховенства закона и подотчетности, а также уязвимость получателей помощи в условиях долгового кризиса ${ }^{117}$. Как будет показано в последнем разделе, это - проблемы, решению которых мог бы способствовать центр по взаимосвязанности ОБСЕ.

В 2010 году, когда Казахстан председательствовал в ОБСЕ, он воспользовался этой возможностью, чтобы поставить на первое место в повестке дня организации экономическое сотрудничество, уделив приоритетное внимание теме наземного транспорта $^{118}$. Еще одну возможность он увидел, когда, отвечая на запросы ряда восточноевропейских и центральноазиатских государств-участников, швейцарское 
председательство в 2014 году уделило повышенное внимание экономическим и экологическим вопросам. Казахстан воспользовался этим для продвижения собственной позиции. В результате возросли и его инициативность, и ожидания в рамках обсуждения взаимосвязанности в ОБСЕ. В 2016-2019 годах Германия, Австрия, Италия и Словакия во время своего председательства продолжили развивать данную тему в различных направлениях. Италия, например, сделала акцент на внедрении цифровых технологий, а Германия тесно увязала взаимосвязанность с вопросами надлежащего управления ${ }^{119}$.

Кульминацией инициатив Казахстана в сфере взаимосвязанности стало лоббирование им создания Тематического центра ОБСЕ по устойчивой взаимосвязанности в столице страны Нур-Султане. Идея была представлена в столице в июне 2017 года на втором подготовительном совещании к Экономическому и экологическому форуму ОБСЕ и затем обсуждалась на встрече Совета министров в Вене в декабре. Двенадцать месяцев спустя во время проведения встречи Совета министров в Милане в 2018 году министр иностранных дел Казахстана Кайрат Абдрахманов вновь поднял вопрос о создании тематического центра. В июле 2019 года на неформальной встрече министров иностранных дел стран ОБСЕ в Словакии это предложение было конкретизировано. Новый министр иностранных дел Бейбут Атамкулов заявил, что центр должен проводить исследования по «взаимосвязанности в ее широком понимании». Посол Казахстана в ОБСЕ Кайрат Сарыбай указал, что предлагаемый центр должен охватывать такие темы, связанные со вторым измерением, как «вопросы устойчивой взаимосвязанности, ... надлежащего управления, “зеленой экономики”, развития новых технологий, предотвращения стихийных бедствий, энергетической безопасности и содействия торговле» ${ }^{120}$. Правительство Казахстана рекомендовало разместить его в Международном финансовом центре в Астане, официально открывшемся в Нур-Султане в середине 2018 года на полпути между аэропортом и центром города ${ }^{121}$. Это обеспечило бы синергетический эффект от сочетания деятельности тематического центра, казахстанских учреждений и ученых расположенного поблизости Университета имени Назарбаева. Конкретные функции центра еще предстоит определить.

Первоначально Казахстан предложил, чтобы расходы по управлению центром взяли на себя он сам и (или) группа «друзей Казахстана». Позже он стал настаивать на том, чтобы расходы покрывались из сводного бюджета ОБСЕ ${ }^{122}$. Есть основания полагать, что такое изменение позиции не было (в первую очередь) вызвано финансовыми соображениями. Учитывая жесткий бюджет ОБСЕ и политику его нулевого номинального роста, что означает сокращение бюджета в реальном выражении, маловероятно, что нынешний Программный офис и тематический центр смогли бы существовать в тандеме, если бы они финансировались из сводного бюджета. В то время как значительная доля расходов ОБСЕ (34\%) приходится на деятельность в странах Юго-Восточной Европы, на страны Центральной Азии также приходится их существенная часть (15\%), что превышает долю как Восточной Европы (4\%), так и 
Южного Кавказа $(2 \%)^{123}$. По этой причине в условиях отсутствия необходимости в осуществлении здесь миростроительной деятельности, поддержания мира или срочных действий по предотвращению конфликтов существенное увеличение доли Центральной Азии в расходах ОБСЕ в обозримом будущем маловероятно. Бывший Генеральный секретарь ОБСЕ Томас Гремингер однажды отметил, что, учитывая жесткие рамки сводного бюджета, ОБСЕ не сможет позволить себе содержать два офиса в Казахстане. Занятая сейчас Казахстаном позиция, согласно которой тематический центр должен финансироваться из сводного бюджета, логически подразумевает, что Программный офис в Нур-Султане должен быть закрыт, хотя публично об этом не говорится.

\section{Сопротивление нормам и лидерские амбиции}

С точки зрения Казахстана, размещение в стране центра помимо перспективы получения непосредственной материальной выгоды позволило бы избежать выполнения неприятных нормативных обязательств и способствовало бы продвижению его роли как лидера в сфере взаимосвязанности. Как отмечается в предыдущем разделе, размещение тематического центра могло бы преследовать цель заменить нынешний Программный офис ОБСЕ в Нур-Султане. На пленарном заседании Совета министров в Базеле в 2014 году заместитель министра иностранных дел Алексей Волков в своем выступлении отметил, что офис может быть закрыт полностью. Хотя данная угроза не была реализована ${ }^{124}$, правительство Казахстана впоследствии неоднократно высказывало идею о необходимости пересмотра мандата этого присутствия, решительно подчеркивая второе измерение и при этом преуменьшая, если не полностью игнорируя, два других. Как и большинство других присутствий на местах в Центральной Азии, статус учрежденного в Казахстане в 1998 году присутствия ОБСЕ уже был понижен до уровня нынешнего Программного офиса. В 2015 году он лишился ряда полномочий, таких как мониторинг судебных разбирательств - наблюдение и сбор информации о судебных слушаниях и процедурах с целью оценки их соответствия стандартам справедливого судебного разбирательства ${ }^{125}$. В 2004 году Казахстан подписал «Астанинское обращение», в котором ОБСЕ критиковалась за якобы имевший место перекос в ее деятельности в пользу человеческого измерения, сопровождавшийся вмешательством во внутренние дела. В 2018 году министр иностранных дел Абдрахманов стал первым представителем властей Казахстана, в письменной форме утверждавшим, что Программный офис выполнил свой мандат и пора поменять направления его деятельности ${ }^{126}$.

Представляется, что власти Казахстана рассматривают размещение в стране официальной структуры ОБСЕ, такой как предлагаемый тематический центр, в качестве способа поменять направленность деятельности ОБСЕ. Вероятно, они видят в создании центра возможность отвлечь внимание от неприятных обязательств, в част- 
ности, в рамках третьего (человеческого) измерения ${ }^{127}$. Такое объяснение вписывается в более широкую тенденцию в рамках ОБСЕ: несколько государств-участников все чаще сопротивляются соблюдению обязательств по документам ОБСЕ и, пользуясь своим правом вето, блокируют назначение нежелательных лиц на руководящие должности в организации ${ }^{128}$.

Еще один важный мотив продвижения казахстанской повестки дня по обеспечению взаимосвязанности - лидерские амбиции руководства. Начиная с 1990-х годов страна активно демонстрирует лидерство на региональном и международном уровнях, выдвигая многочисленные инициативы по сотрудничеству. Так, первый президент Казахстана Нурсултан Назарбаев предложил следовать модели европейской интеграции и настаивал на интеграции в рамках Евразийского союза ${ }^{129}$. Председательство Казахстана в ОБСЕ в 2010 году также было явным проявлением стремления к лидерству ${ }^{130}$. Страна в значительной степени проложила путь к объявлению Центральной Азии зоной, свободной от ядерного оружия. С некоторым успехом Казахстан активно позиционирует себя как страну, активно реализующую амбициозную дипломатическую и внешнеполитическую повестку дня, в частности, в качестве честного мирного посредника, например, в качестве принимающей стороны процесса урегулирования в Сирии ${ }^{131}$. Пожалуй, не случайно на упомянутой выше неофициальной встрече министров иностранных дел стран ОБСЕ в Словакии в 2019 году представитель Казахстана не только выступил с предложением разместить в стране центр по взаимосвязанности, но и упомянул о намерении провести в Казахстане встречу по урегулированию в Афганистане ${ }^{132}$. Таким образом, страна в какомто смысле стала экспортером региональной и международной безопасности. Инициативы в области взаимосвязанности, выдвигаемые в Нур-Султане и Вене, также направлены на обеспечение ведущей роли и консолидацию все более активного участия Казахстана в региональных и международных делах. Международный финансовый центр, в котором предлагается разместить центр взаимосвязанности, был создан правительством Казахстана с целью превращения страны в один из центров глобальной финансовой системы ${ }^{133}$. Следуя примеру других стран, в частности, государств Персидского залива, финансовый центр позиционирует себя «в качестве регионального центра бизнеса и финансов, связывая экономики стран Центральной Азии, Кавказа, ЕАЭС, Западного Китая, Монголии, Ближнего Востока и Европы» ${ }^{134}$.

Однако лидерство Казахстана не бесспорно. Так, Узбекистан и Кыргызстан также хотят чтобы переговоры по Афганистану проходили у них, демонстрируя тем самым свою роль как лидера. Узбекистан - страна с самым многочисленным населением из пяти государств региона - с подозрением относится к лидерским амбициям руководства Казахстана, которые получили бы подтверждение в случае создания центра по взаимосвязанности ${ }^{135}$. По этой причине в ходе дальнейшего обсуждения данного предложения Казахстану важно серьезно отнестись к возражениям его южных соседей и пойти им навстречу. 
В связи со стремлением уйти от обсуждения вопроса о выполнении обязательств и повысить международный престиж большую роль в продвижении Казахстаном его повестки дня играют статусные соображения. Похоже, в Нур-Султане крепнет убеждение, что присутствие Программного офиса ОБСЕ в стране формирует представление о Казахстане (по их мнению, ошибочное) как о стране с проблемными внутриполитическими условиями. Этот дискомфорт отчасти понятен, так как Казахстан по ряду показателей - инвестиционный климат, экономический рост, верховенство права и общая политическая стабильность - выделяется в лучшую сторону на фоне некоторых своих соседей, таких как Туркменистан и Таджикистан. На этом фоне предлагаемый тематический центр отражает желание Казахстана разместить у себя полноценный институт ОБСЕ, а не офис для государства-участника, «действительно нуждающегося» в нем. На неофициальной встрече министров иностранных дел стран ОБСЕ в Словакии в 2019 году казахстанская делегация заявила, что одна из целей инициативы по созданию центра - обеспечить географически более сбалансированное размещение институтов ОБСЕ ${ }^{136}$.

Трудно предположить, будет ли создан центр ОБСЕ по взаимосвязанности. При условии достаточного финансирования Постоянный совет в конечном итоге должен будет принять решение по этому вопросу на основе консенсуса всех 57 государствучастников. Похоже, что Казахстану пока не хватает решительной поддержки со стороны других четырех центральноазиатских государств ${ }^{137}$. Но и ряд других государств-участников, включая по крайней мере одно крупное государство Европейского союза, не торопятся поддержать данную идею. Поэтому Казахстану и другим заинтересованным странам следует прояснить, какие функции будет выполнять центр, и учесть возражения тех государств, которые не поддержали инициативу.

\section{Заключительные положения и рекомендации}

ОБСЕ призвана сыграть свою роль в обеспечении экономической и транспортной взаимосвязанности, а Казахстан продемонстрировал заметную лидирующую роль в региональном и международном сотрудничестве и обеспечении стабильности. Поэтому к его инициативе следует отнестись серьезно. Однако поддержка инициатив Казахстана по повышению взаимосвязанности не должна поощрять игнорирование обязательств в рамках первого и третьего измерений ОБСЕ. Поэтому следует использовать возможности, которые открывает взаимосвязь всех трех измерений. Строго говоря, взаимосвязанность - тема второго измерения. Однако так как она призвана служить укреплению политического доверия и транспарентности и способствовать более эффективному управлению границами, она имеет отношение и к первому измерению. Имеет она отношение и к третьему - человеческому - измерению безопасности. Как боннский Документ 1990 года, так и решение Совета министров 2016 года содержат прямое упоминание уважения прав человека. Тема надле- 
жащего управления, имеющая отношение к третьему измерению, часто упоминается с тех пор как Германия во время своего председательства в ОБСЕ выдвинула ее на передний план обсуждения в ОБСЕ вопросов взаимосвязанности. Хотя в контексте ОБСЕ надлежащее управление преимущественно формулируется в экономических терминах (борьба с коррупцией, отмыванием денег), оно также предполагает «полное соблюдение верховенства права» ${ }^{138}$. Это имеет уже прямое отношение к третьему измерению, поскольку ОБСЕ исходит из того, что верховенство права лежит в основе уважения прав человека и демократизации. Военно-политические вопросы и вопросы гуманитарной безопасности остаются центральными для обеспечения комплексной и устойчивой взаимосвязанности, как ее понимают в настоящее время в ОБСЕ, и от этого нельзя отказываться.

Следует признать, что ОБСЕ, учитывая ее ограниченные ресурсы и больший опыт других организаций, таких как ЕС, Всемирный банк, Всемирная торговая организация, Европейский банк реконструкции и развития и ЕЭК ООН, - не самая заметная структура в области взаимосвязанности. Поэтому ОБСЕ должна выступать в качестве площадки, дискуссионного форума или посредника по распространению знаний в рамках проектов по повышению взаимосвязанности в регионе ОБСЕ ${ }^{139}$. Это - функции, с помощью которых она может вносить свой вклад. Предлагаемый центр по взаимосвязанности мог бы, в частности, выполнять задачи аналитического или информационно-координационного центра по устойчивым проектам, связанным с торговлей и транспортом, помогая избегать или смягчать такие проблемы, как недостаточная экологическая устойчивость и экономическая целесообразность, неудовлетворительная стандартизация в торговле, а также отсутствие транспарентности и подотчетности. Еще одна серьезная проблема - уязвимость в условиях долгового кризиса не столько Казахстана, сколько других государств-участников, таких как Кыргызстан, Таджикистан и Монголия ${ }^{140}$. Что касается последней проблемы, то центр по взаимосвязанности мог бы, опираясь на соответствующие исследования, консультировать потенциальных заемщиков по будущим проектам, решению долговых проблем и в целом помогать определять стандарты устойчивого финансирования. Выполняя предложенные функции путем проведения исследований, организации семинаров и конференций, центр мог бы выступать в качестве катализатора торговли и транспорта в регионе ОБСЕ. Это было бы актуально, в частности, для пяти центральноазиатских стран, которые значительно расширили свое торгово-экономическое сотрудничество с 2014 года благодаря нескольким инфраструктурным проектам, таким как газопровод из Туркменистана в западный Китай через Узбекистан и Казахстан, построенный в 2006 - 2009 годах, и, по всей вероятности, осуществят еще несколько проектов ${ }^{141}$. Учитывая скромные финансовые возможности и опыт ОБСЕ в некоторых вопросах взаимосвязанности, центру нужно будет тесно сотрудничать с другими аналогичными организациями, занимающимися вопросами развития, инфраструктуры и финансирования. 
Оттачивая свой профиль в сфере взаимосвязанности, ОБСЕ следует также использовать свои дополнительные преимущества, которыми она обладает как организация, занимающаяся вопросами безопасности, в сравнении со структурами, ориентированными на более технические аспекты проблемы. Для этого ей следует подчеркивать связь между безопасностью и взаимосвязанностью. Управление границами, политические меры укрепления доверия, соглашения о демаркации границ и решению проблем, носящих трансграничный характер, а также энергетическая безопасность - вот темы, которыми должен заниматься будущий центр.

При дальнейшем продвижении инициативы о создании центра по взаимосвязанности Казахстану с его претензией на лидерство в этой области следует избегать отчуждения других центральноазиатских стран. С 2016 года, Узбекистан, «вдвойне удаленный от моря» ${ }^{142}$, в частности, также стал сторонником взаимосвязанности, уделяя особое внимание отношениям между центральноазиатскими странами ${ }^{143}$. Любые инициативы, выдвигаемые Казахстаном в целях содействия повышению взаимосвязанности, должны объединять другие заинтересованные центральноазиатские государства, а не отталкивать их. Этого можно добиться, в частности, путем обеспечения достаточного представительства экспертов из Узбекистана в предлагаемом центре. В целом Казахстану и другим заинтересованным странам следует конкретнее изложить функции центра и постараться учесть интересы тех, кто пока не поддержал данный проект.

\section{Примечания}

102 Connectivity // Официальный сайт ОБСЕ. URL: https://www.osce.org/oceea/446224

103 Представленная в статье информация взята из цитируемых первичных и вторичных источников, одного интервью не для записи и нескольких интервью, проведенных в июле и августе 2020 года.

104 См.: Wolff S. Economic diplomacy and connectivity: What role for the OSCE? - Birmingham: University of Birmingham, Institute for Conflict, Cooperation and Security, 2018. P. 6. URL: https://www.birmingham.ac.uk/Documents/college-social-sciences/government-society/iccs/new s-events/2018/Osce-Report.pdf.

105 Keohane R.O., Nye J. Power and Interdependence: World Politics in Transition. - Boston: Little, Brown, 1977.

106 См., в частности: Kemoklidze N., Wolff S. Trade as a Confidence-Building Measure in Protracted Conflicts: The Cases of Georgia and Moldova Compared // Eurasian Geography and Economics. 2020. No 3. P. 305-332; Gartzke E., Quan Li, Boehmer Ch. Investing in the Peace: Economic Interdependence and International Conflict// International Organization/ 2001. No 2. P. 391-438.

107 Keohane R.O., Nye J. Op. cit. P. 14-16.

108 Godehardt N., Postel-Vinay K. Connectivity and geopolitics: Beware the "new wine in old bottles" approach. SWP Comment 2020/C 35. 2020, P. 4-5. URL: https://www.swp-berlin.org/en/pu blication/connectivity-and-geopolitics-beware-the-new-wine-in-old-bottls-approach/. 
109 Документ боннской Конференции по экономическому сотрудничеству в Европе, проведенной во исполнение соответствующих положений итогового документа Венской встречи Совещания по безопасности и сотрудничеству в Европе. Бонн, 11 апреля 1990. С. 2 4. // Официальный сайт ОБСЕ. URL: https://www.osce.org/files/f/documents/8/e/14086.pdf

110 Заключительный документ одиннадцатой встречи Совета министров ОБСЕ в Маастрихте, 1-2 декабря 2003. С. 16. // Официальный сайт ОБСЕ. URL: https://www.osce.org/ru/mc/4053 8.

111 OSCE economic and environmental activities. // Официальный сайт ОБСE. URL: https://www. osce.org/oceea.

112 Передовая практика на пунктах пересечения границы: содействие торговле и транспорту Справочник ОБСЕ - ЕЭК ООН. - ОБСЕ; ЕЭК ООН, 2012. // Официальный сайт ОБСЕ. URL: https://www.osce.org/files/f/documents/0/e/99872.pdf.

113 OSCE/UNECE, Inland Transport Security Discussion Forum Proceedings. - OSCE; UNECE, 2012. // Официальный сайт ОБСЕ.

URL: https://www.osce.org/files/f/documents/b/6/99852.pdf

114 Pomfret R. The Central Asian Economies in the Twenty-First Century: Paving a New Silk Road. - Princeton; Oxford: Princeton University Press, 2019. P. 215-223.

115 Vinokurov E. Introduction to the Eurasian Economic Union. Cham: Palgrave Macmillan, 2018. P. 134-137.

116 Kassenova N. China's Silk Road and Kazakhstan's Bright Path: Linking Dreams of Prosperity // Asia Policy. 2017. No 24. P. 111-112.

117 Peyrouse S., Gaël Raballand. Central Asia: The New Silk Road Initiative's Questionable Economic Rationality // Eurasian Geography and Economics. 2015. No 4. P. 405-420.

118 Dunay P. Kazakhstan's Unique OSCE Chairmanship in 2010// OSCE Yearbook 2011 / IFSH (ed.). Baden-Baden: Nomos, 2012. P. 53.

119 Smolnik F. Cooperation, trust, security? The potential and limits of the OSCE's economic and environmental dimension. SWP Research Paper 2019/RP 16, 2019. P. 17-19. URL: https://www. swp-berlin.org/en/publication/the-potential-and-limits-of-the-osces-economic-and-environmental -dimension/.

120 Altynsarina E. Kazakhstan announces initiatives to reinforce OSCE goals // The Astana Times. 2019. 11 July 2019. URL: https://astanatimes.com/2019/07/kazakhstan-announces-initiatives-toreinforce-osce-goals/.

121 Компании и учреждения, зарегистрированные в Международном финансовом центре (в настоящее время их почти 600), пользуются преимуществами налоговых льгот, современного финансового регулирования и коммерческого права, основанного на английском праве. Финансовый центр также внедрил механизмы арбитража и разрешения споров, которые могут служить образцом для остальной части страны. Таким образом правительство желает улучшить инвестиционный климат и, соответственно, привлечь инвесторов в Казахстан. См.: Zambrana-Tévar N. The new Court of the Astana International Financial Centre: Promoting the Rule of Law or Giving up on the Rule of Law? // Central Asia Business Journal. 2019. Fall. P. 37-48.

122 Интервью с сотрудником ОБСЕ из Центральной Азии, июль 2020 года.

123 Данные сводного бюджета мсм.: Ежегодный доклад за 2019 год. - Вена: ОБСЕ, 2020. С. 98. URL: https://www.osce.org/files/f/documents/5/b/462235_0.pdf.

124 Правительство в принципе могло бы это сделать, поскольку каждое присутствие раз в год нуждается в продлении его мандата, который утверждается Постоянным советом на основе консенсуса. Так, выражая недовольство деятельностью бюро ОБСЕ в Баку, азербайджанское руководство воспользовалось своим правом вето и добилось его закрытия в 2016 году. 
125 Mayer S. Walking alone, walking together? OSCE-EU relations in Central Asia. OSCE Academy Bishkek. Policy Brief No 62, 2020. P. 3-4. URL: http://osce-academy.net/upload/file/62.pdf.

126 Интервью с сотрудником ОБСЕ из Центральной Азии, июль 2020 года.

127 Ныне действующий Программный офис ОБСЕ в Нур-Султане занимается всеми тремя измерениями.

128 Kemp W. Executed structures: Leadership crisis in the OSCE // Security and Human Rights Monitor. 2020. 14 July. URL: https://www.shrmonitor.org/executed-structures-leadership-crisis-i n-the-osce/.

129 Karabayeva A. Leaders, Ideas, and Norm Diffusion in Central Asia and Beyond // Asian Journal of Comparative Politics. 2019. P. 4-9.

130 Dunay P. Op. cit. P. 57.

131 Vanderhill R., Joireman S.F., Tulepbayeva R. Between the Bear and the Dragon: Multivectorism in Kazakhstan as a Model Strategy for Secondary Powers // International Affairs. 2000. No 4. P. 986-990.

132 Altynsarina E. Kazakhstan announces initiatives to reinforce OSCE goals // The Astana Times. 2019. 11 July. URL: https://astanatimes.com/2019/07/kazakhstan-announces-initiatives-to-reinfo rce-osce-goals/.

133 Chakrabarti S. EBRD's vision for Astana International Financial Centre // The Astana Times. 2016. 25 May 2016. URL: https://astanatimes.com/2016/05/ebrds-vision-for-astana-international -financial-centre/

134 Добро пожаловать в МФЦА // Официальный сайт Международного финансового центра «Астана». URL: https://aifc.kz/ru/.

135 Интервью с сотрудником ОБСЕ из Центральной Азии, июль 2020 года.

136 Elya Altynsarina, "Kazakhstan announces initiatives to reinforce OSCE goals", The Astana Times, 11 July 2019. // https://astanatimes.com/2019/07/kazakhstan-announces-initiatives-to-rei nforce-osce-goals/.

137 Интервью с сотрудником ОБСЕ из Центральной Азии, июль 2020 года.

138 Good governance // Официальный сайт ОБСЕ. URL: https://www.osce.org/oceea/446335.

139 См.: Wolff S. Op cit. P. 24-27.

140 Hurley J., Morris S., Portelance G. Examining the debt implications of the Belt and Road Initiative from a policy perspective. Center for Global Development Policy Paper 121. March 2018. P. 16-19. URL: https://www.cgdev.org/sites/default/files/examining-debt-implications-belt-and-roa d-initiative-policy-perspective.pdf

141 Pomfret R. Kooperation im Politikfeld Handel // Die politischen Systeme Zentralasiens: Interner Wandel, externe Akteure, regionale Kooperation / J. Lempp, S. Mayer, A. Brand (eds.). Wiesbaden: Springer VS, 2020. P. 318-322.

142 То есть граничащий исключительно со странами, не имеющими выхода к морю.

143 Indeo F. New Trends in Central Asian Connectivity // Monitoring Central Asia and the Caspian Area: Development Policies, Regional Trends, and Italian Interests, Eurasiatica 13 / C. Frappi, F. Indeo (eds.). - Venice: Edizioni Ca'Foscari, 2019. P. 65-80; Weitz R. Uzbekistan's new foreign policy. - Central Asia-Caucasus Institute and Silk Road Studies Program. Silk Road Paper. January 2018. P. 9-12, 31-42. URL: https://silkroadstudies.org/resources/pdf/SilkRoadPapers/1801 Weitz.pdf. 